\title{
Innovation of Talent Training Mode of Library and Information Major
}

\author{
Xueyang Sun ${ }^{1, a^{*}}$, Jie Dong ${ }^{1, b}$ and Yi Ren ${ }^{1, c}$ \\ ${ }_{1}^{1}$ No.9, Hunnan East Road, Hunnan New District, Shenyang City, Liaoning, P.R.China \\ a120673434@qq.com, b623236930@qq.com, ${ }^{c} 1181134429 @ q q . c o m$
}

Keywords: Innovation and entrepreneurship; Evaluation; Cultivating talent

\begin{abstract}
With the development of the times, the library and information professionals take the digital information resources as the management object and mainly operate the modern technology and equipment such as computers. Library and information personnel need to learn new theories, new methods and new technologies for their work. How to train library and information professionals in the new era is a problem that should be solved in colleges and universities. This paper discusses the new training mode of library and information professionals.
\end{abstract}

The Training Mode of Library and Information Professional Talents under the Background of Management, Implement and Evaluation.

Management, Implement and Evaluate, Focus on Implement. At present, the management and evaluation has seriously restricted the healthy development of the main university, restricted the establishment of the modern education system in China, and restricted the improvement of educational governance level and the improvement of educational quality.

For this reason, the third Plenary session of the 18th CPC Central Committee decided to expand the provincial government defines right to co-ordinate education and the autonomy of university, that is, to promote the central government to delegate power to local governments and the government to delegate power to Universities. [1]

After Decentralization, what about the University? Many participants were of the view that the core of education lies in running an university after the management and grading system has left behind, and it is necessary not only to clarify the power and responsibility of running an university according to law, but also to win respect and affirmation with its characteristics and vitality.

Gu Mingyuan, a professor at Beijing normal University, said the university should have clear powers and responsibilities and run universities in accordance with the law. The educational administration should believe in the university and delegate its powers to the faculty and the students. [2]

After Decentralization, how does Society Evaluate it? Qu Shaobing, director of Guangzhou Education Bureau, believes that the guidance of the evaluation link is very important. At present, the third party evaluation organizations in our country are still in the development stage, so we should strengthen the cultivation and form a group of social organizations with the qualifications of educational evaluation and educational quality monitoring as soon as possible.[3]

Some experts pointed out that governments, universities, and social and professional institutions need to realize that management and grading will be the "new normal" for future education reform; and that the evaluation of independent third-party organizations should be regarded as an important force in improving management and running universities. In the final analysis, the purpose of managing the separation of grades is to promote the healthy development of education in an open educational environment and to serve the fundamental goal of "building a person by virtue".

The Key Points in the Management Evaluation: Management-"Knowledge and Action as a whole" and "Learning is Practice" Based on Feedback Mechanism

Environment for the training of Library and Information Professionals in the New era. With the gradual integration of modern science and technology with the work of library and information, new requirements have been put forward for library and information professionals in the breadth and depth 
of knowledge. In the past, library and information workers used to take printed literature resources as the management object, and the processing and retrieval of documents were provided and utilized mainly by manual operation. Now, the management objects are digital information resources. The operation of modern technology and equipment, such as computers, is a new field of work. Library and information personnel need to learn new theories, new methods and new technologies.

Theory of "Integration of knowledge and Action". "Integration of knowledge and practice" was put forward by Wang Yangming, a scholar in Ming Dynasty, and was widely used by the world. "Theory is combined with practice", "practice is the only test of truth" can be used as an interpretation of the unity of knowledge and practice. But the truth is that what Wang Yangming wants to do is not just to separate theory from practice, and then verify each other.

The Training Model of Innovative and Entrepreneurial Talents for Library and Information Specialty. We divide the library and information professional innovative entrepreneurial talents training model into three stages: the basic platform of entrepreneurship teaching, the platform of simulation and training of entrepreneurship, and the comprehensive platform of entrepreneurial practice.

The first stage of the training model of library and information professional innovative entrepreneurial talents is the cultivation of students' innovative and entrepreneurial ability. At this stage, students will learn the necessary reserve knowledge, have certain abilities and qualities. In terms of courses, there are courses to enhance entrepreneurship awareness, such as "Entrepreneurship Theory", "Marketing", "career Planning and Development of College students" and so on. It lays a solid theoretical foundation for students in the later stage of simulation and actual combat.

The most important part of the library and information professional innovation and entrepreneurial talent training model is in the medium-term entrepreneurial simulation training platform. In practical training, the practical training links are designed according to the actual conditions by the participation of the teachers and cooperation with various off-campus companies. With the help of off-campus companies, the existing resources are used to simulate training, and feedback is obtained through a large amount of data and data analysis. Guide students in each simulation to achieve innovation in the link, practice to maintain through data analysis of thinking and learning, and in the analysis of the process of conclusion timely application to practice. Thus, the students' thinking ability of "knowing and doing as one" has been trained.

When the students set up the thinking mode of "knowing and doing as one" in the simulation, they can go to the actual combat platform and start their own business independently. In the process of starting a business, students should be reminded to keep the thinking mode of "knowing and doing as one", and apply the exercise gained in the last stage to the final practice. The school provides funds and corresponding venues for students to choose their own solutions to achieve innovative entrepreneurship. Finally, the result is measured by the evaluation of management evaluation to judge the effect of students' innovative entrepreneurial model. 


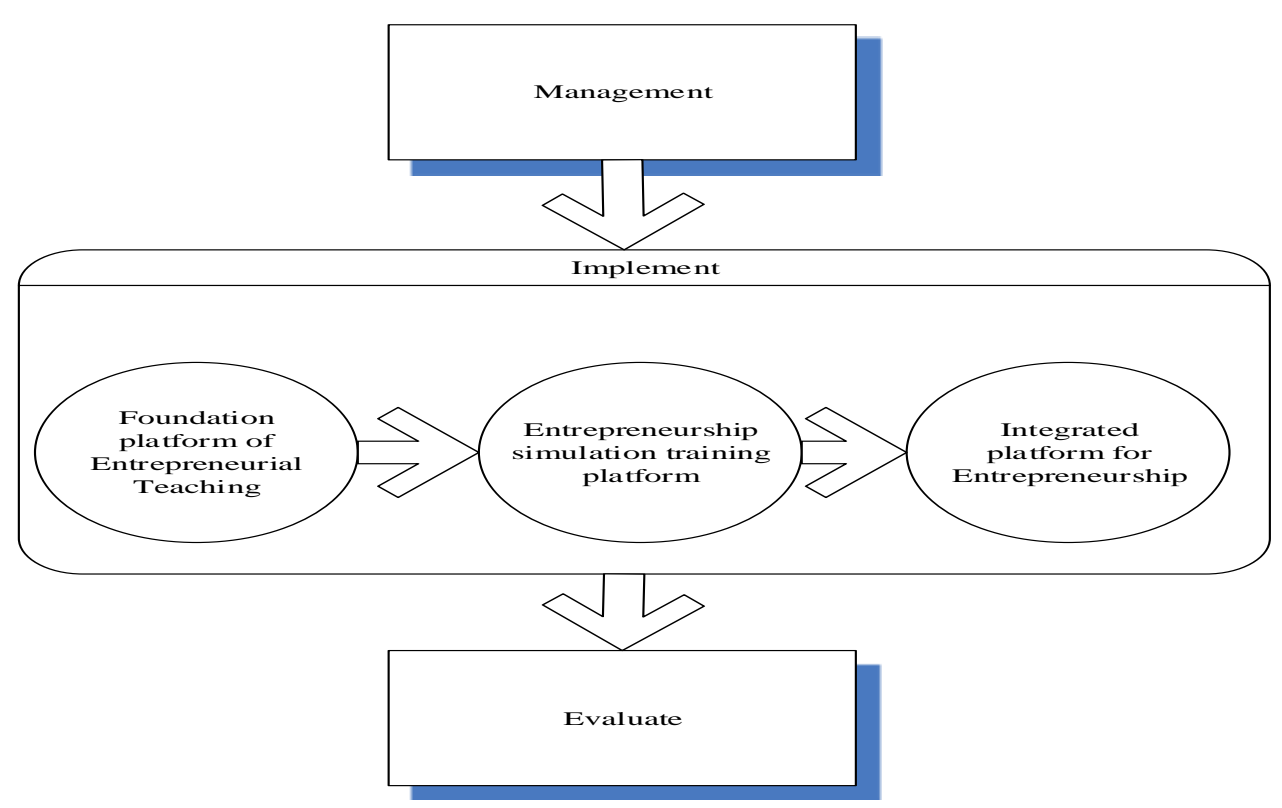

Figure 1. Management and Implement and Evaluate

Design of "knowledge and practice as a whole" Innovation and Entrepreneurial Talent training Mode Entrepreneurial Simulation Link Design. In order to promote the students to be able to know and act as a whole, practice fusion of thinking, theory feedback to the effect of practice. Must take certain method to guide, the exercise student's thought way. The emphasis is on the design of the second stage entrepreneurship simulation training link.

The body of knowledge and action emphasizes the conscious consciousness in the whole practice. In the whole student practice, it is necessary to set up links that can remind students to be aware of what they are aware of while they are practicing, so as to urge students to think and draw conclusions from the analysis of data and the actual situation at every tiny pause point. This conclusion is theoretical knowledge.

Allows students to quickly apply the conclusions they have just reached in practice, observe effects, and continue to adjust. Verify over and over again. The truth of the knowledge is the truth.

In order to facilitate the inspection, the whole innovation start - up stage can be divided into several and small steps, each of which is summarized. Then, the practice effect of knowledge and the supplement to the knowledge after practice are paid attention to at this point .

Learning as a practice based on feedback Mechanism. "The learning and practice based on feedback mechanism" is just like the battle of the soldiers. The generals watch the enemy and me war below. It is impossible to wait until the end of the war to sum up, but to adjust the instructions at any time, at the same time, to observe the change of the enemy, and to change his tactics according to the data of the enemy. Then, on subsequent battlefields, we verify that we have summed up the correctness of the tactics.

In the innovation and entrepreneurship, we may think that the market we need to do is an enemy battlefield. We have generals and soldiers. The generals are always conscious of the self-awareness that they are learning and practicing. The soldiers are the knowledge base of the students' reserve and the constantly adjusting way of work.

After the continuous analysis of the feedback of the market data, students can constantly adjust their work and further improve their knowledge at every point of time, and continue to practice the effectiveness of such adjustments, and finally achieve good results.

The students remit their knowledge in thinking and reapply their knowledge to practice in the adjustment. It is based on the spiral rise of the feedback mechanism, that is, learning to practice, so that the project of innovation and entrepreneurship is done well. It has achieved the thinking exercise and the good effect of the training of talents. 
Entrepreneurial Simulation training platform Model. In this simulation stage, feedback mechanisms can be used, or feedback mechanisms can be used. Specific implementation steps: a creative venture project.

Project initialization: determine the project name, set the final project goal.

Detailed design of the project process, the process is divided into specific detailed steps or according to the time, divided into a number of detailed time points.

The implementation steps of the project "Learning is practice based on feedback Mechanism" lead students to think and discuss through the feedback data in the last step, and what kind of conclusion can be drawn. After the conclusion is sorted out in writing, the learning model of spiral rise is adopted in combination with the theory to continue the practice of the next step. Learning is learning, and learning is also thinking. Learn by thinking, think by learning. Do not learn and think as a cause and effect, but a combination of one, in order to achieve good innovative entrepreneurial talent training results.

\section{Discussion on the Evaluation Method of Innovative Entrepreneurial Talents Training Model Based on "Knowledge And Practice"}

It is a compulsory course to realize the diversified innovation and entrepreneurship education of teaching evaluation index system. In order to make this compulsory course achieve certain teaching effect, colleges and universities should realize the diversification of two teaching evaluation systems. One is to change the traditional mode of assessing students' learning achievement, to realize the diversification of achievement evaluation, to incorporate innovative entrepreneurial ability into the comprehensive evaluation system of students, and to add the evaluation of innovative entrepreneurial consciousness and ability to the quantitative comprehensive evaluation system.

In the examination of each course achievement, the module of innovative entrepreneurial ability and quality is infiltrated, and the practical ability and innovative method of students applying professional knowledge to solve practical problems are examined. Second, it is necessary to change the evaluation mode of teachers' teaching effect by educational departments and colleges, to realize the diversification of teachers' comprehensive evaluation, to cultivate students' ability to innovate and to set up business, and to teach students' professional practice effect. To guide the students to win the prize, etc., into the comprehensive evaluation system of teachers, while taking the examination results as an important index of professional title promotion and performance salary.

\section{Summary}

The mode of cultivating innovative talents of library and information specialty based on learning and practice based on feedback mechanism should take the market demand as the vane, improve teaching methods continuously, and create an advantage platform suitable for professional development. In order to improve students' comprehensive practical ability and innovative entrepreneurial ability, constantly improve the library and information major training program, to achieve a seamless interface between graduates and industry needs.

\section{References}

[1] F.Wang, H.Y. Shi and X.M.Ji: Journal of the China Society for Scientific and Technical Information, Vol. 34 (2015) No.6, p.581(In Chinese)

[2] H.J. Cao: A Research report on the Mode of College students' Innovation and Entrepreneurship (Posts and Telecommunications Press, China 2016),p.56(In Chinese)

[3] F.L. Fang: Research and practice of Talent training Model based on "Innovation and Entrepreneurship" (Tourism Education Press, China 2017),p.12(In Chinese) 